\title{
Evaluation of Abiotic Stress Induced Physiological and Biochemical Changes in Trigonella Foenum-Graecum
}

\author{
Sindhu S Nair ${ }^{1}$, Prathika Gopalakrishnan ${ }^{1}$, Sindhuja Umesh ${ }^{1}$, Akshaya $\mathrm{S}^{1}$, \\ Abhilasha $\mathrm{VG}^{1}$ \\ Department of Biotechnology, Mount Carmel College Autonomous, Bengaluru-560052, India
}

\begin{abstract}
Plants species are often being exposed to unfavourable environmental conditions such as various abiotic stress factors. These factors play an important role in determining crop productivity and yield. Some examples of abiotic stresses include decreased water availability, extreme temperature, and decreased availability of soil nutrients, excess of toxic ions, excess of light, exposure to heavy metals. The ability of plants to acclimatise to different environments depends mainly on photosynthesis and reproduction. It has been understood after exploring and understanding plant abiotic responses at the whole-plant, physiological, biochemical, cellular and molecular levels that abiotic stresses elicit complex cellular responses. The aim of our study is to determine and understand the effects of salinity, osmotic stress and heavy metal stress on Trigonella foenum-graecum. The results suggest that these abiotic stress factors cause significant reduction in seed germination and also cause subsequent decrease in biochemical constituents like proteins, $\beta$-amylase, total soluble sugars and starch. Different concentrations of the stress also altered the relative water content. The results also indicated that certain parameters like total phenolics, free proline content, glycine betaine activity and catalase enzyme activity increased significantly with increase in the stress levels.
\end{abstract}

Keywords: Abiotic stress, catalase, reactive oxygen species, seed germination, Trigonella foenum-graecum.

\section{Introduction}

There is an alarming increase in the world population and it is projected to rise by more than one billion by 2030 and over 2.4 billion by 2050 .Therefore, it has been estimated that to meet the demands of the increasing population, food production by agricultural practices must be increased by 70 percent by 2050 . The currently existing and projected changes in abiotic stresses such as drought, salinity, cold, heat and heavy metal will not only affect the plant growth , it will significantly limit the productivity and it is the leading cause of crop losses worldwide and thus affect our ability to feed the population.[1,2]

Salinity is a major abiotic stress. Depending on severity and duration of the stress its causes changes in various metabolic and physiological processes and ultimately inhibits crop production [4-7]. Soil salinity initially represses plant growth in the form of osmotic stress which is then followed by ion toxicity $[4,5]$. Osmotic stress in the initial stage of salinity stress causes various physiological changes, such as interruption of membranes, nutrient imbalance, impairs the ability to detoxify reactive oxygen species (ROS), differences in the antioxidant enzymes and decreased photosynthetic activity [3,5].

Salinity stress is also considered as a hyper ionic stress which causes the accumulation of $\mathrm{Na}+$ and $\mathrm{Cl}-$ ions in plant tissues exposed to soils with high $\mathrm{NaCl}$ concentrations. Entry of both $\mathrm{Na}+$ and $\mathrm{Cl}-$ into the cells causes severe ion imbalance and excess uptake might cause significant physiological disorder(s). High $\mathrm{Na}+$ concentration inhibits uptake of $\mathrm{K}+$ ions which is an essential element for growth and development that results into lower productivity and may even lead to death [4]. In response to salinity stress, the production of ROS, such as singlet oxygen, superoxide, hydroxyl radical, and hydrogen peroxide, is enhanced [8,9]. Salinityinduced ROS formation can lead to oxidative damages in various cellular components such as proteins, lipids, and DNA, interrupting vital cellular functions of plants.

Osmotic stress is reported to reduce plant growth and productivity. Osmotic stress is said to cause the accumulation of the phytohormone abscissic acid (ABA), which induces several responses to osmotic stress. Osmotic stress signalling consists of an ABA-dependent and an ABA-independent pathway. Osmotic stress also caused increased ROS generation, which in turn elicits various cellular signalling networks resulting into physiological damage to plant cell. [10]. Heavy metal pollution is being considered as one of the important environmental problems worldwide. The remediation of metal pollutants from the soil, water and air is difficult because, unlike organic pollutants which degrade to harmless small molecules, toxic elements, such as lead, mercury, cadmium, copper and zinc, are immutable by biochemical reactions. [11]

Lead $(\mathrm{Pb})$ is considered as one of the most hazardous pollutants of the environment and $\mathrm{Pb}$ pollution is a growing ecological concern due to its impact on human health and environment. The main sources of $\mathrm{Pb}$ pollution in the environment are mining and smelting of $\mathrm{Pb}$ ore, industrial effluents, fertilizers, pesticides, and municipal sewage sludge .Lead toxicity leads to decreases in the percentage of seed germination, as well as 
growth, dry biomass of roots and shoots, disruption of mineral nutrition, reduction in cell division and inhibition of photosynthesis. [12]. Lead is reported to produce reactive oxygen species (ROS) and enhance antioxidant enzyme activity in plants. Oxidative stress gives rise to ROS production which intern causes many harmful effects in plant cells, such as inhibition of photosynthetic activity, inhibition of ATP production, lipid peroxidation, and DNA damage. ROS damages cell membranes, nucleic acids and chloroplast pigments. [13]. The present study focuses on the evaluation of the physiological and biochemical changes induced by salinity, osmotic and heavy metal (Lead) stress on Trigonella foenum-graecum.

\section{Salinity stress}

\section{Materials And Methods}

\section{Collection of Plant material and Germination}

Seeds of Trigonella foenum-graecum were collected locally from south Bangalore and were used for the germination test. Fenugreek seeds were sterilized with $0.1 \%$ mercuric chloride for 5 min and washed thoroughly with distilled water. They were then placed to germinate in Petri dishes, distilled water (control) and different concentration of $\mathrm{NaCl}$ solutions $(10,30,50$ and $100 \mathrm{mM} \mathrm{NaCl})$ at room temperature $\left(25^{\circ} \mathrm{C}\right)$ in light. In each treatment, 5 Petri plates (each containing 25 seeds) were used. The seeds were considered germinated when the radical length reached $2 \mathrm{~mm}$ and the cumulative germination percentage was determined. [14]

\section{Seedling analysis}

Germinated seeds in distilled water and in saline solutions were sampled after 7 days from the beginning of incubation and then germination process was stopped. The tissues were weighed to obtain the fresh weight. The dry weight was obtained after drying the tissue at $75^{\circ} \mathrm{C}$ for $48 \mathrm{~h}$ and then the tissue water content was calculated as based on the (FW-DW/DW) ratio. [14]

\section{Determination of starch content}

Batches of 500mg of cotyledon pairs or axes were homogenized in an ice-cold mortar and pestle in a volume of $16 \mathrm{ml} \mathrm{80 \%} \mathrm{(v/v)} \mathrm{ethanol.} \mathrm{The} \mathrm{homogenate} \mathrm{were} \mathrm{centrifuged}\left(30000 \mathrm{xg}, 10 \mathrm{~min}\right.$ at $\left.2^{\circ} \mathrm{C}\right)$ and then perchloric acid $(\mathrm{HClO} 4 ; 6 \mathrm{ml}, 30 \%$, v/v) was added to solubilize starch from the pellet. The slurry was left at room temperature for $6 \mathrm{~h}$, starch was detected with I2-KI reagent prepared by diluting $0.1 \mathrm{ml}$ stock solution $(0.06 \mathrm{~g} \mathrm{I} 2$ and $0.60 \mathrm{~g} \mathrm{KI}$ in $10 \mathrm{ml}$ deionized water) with $0.05 \mathrm{M} \mathrm{HCl}$ just prior to the assay. Samples of $0.5 \mathrm{ml}$ starch solution were mixed with $0.5 \mathrm{ml} \mathrm{I} 2-\mathrm{KI}$ reagent, $1 \mathrm{ml} 30 \%$ (v/v) perchloric acid and then were vortexed and left standing at room temperature. The absorbance $(620 \mathrm{~nm})$ of the samples was compared to that of the standard curve of 0 to $5 \mathrm{mg} / \mathrm{ml}$ which was obtained using soluble starch dissolved in $30 \% \mathrm{HClO} 4$ and detected with the same I2-KI reagent. The assay was conducted in triplicate for each sample. [17]

\section{Determination of Soluble sugars}

Three replicates of cotyledons or axes samples of germinated seeds were suspended in test tubes with 3 $\mathrm{ml}$ of $80 \%$ ethanol, the extract was evaporated to dryness in hot air oven and the residue was dissolved in $20 \mathrm{ml}$ of distilled water. Total soluble sugars were determined by the phenol sulphuric acid method using glucose as standard. [18]

\section{Determination of $\square$-Amylase activity}

The seeds were homogenised with $4 \mathrm{ml}$ of ice cold $16 \mathrm{mM}$ sodium acetate buffer $(\mathrm{pH} 4.8)$ and centrifuged at $12000 \mathrm{~g}$ for $15 \mathrm{mins}$. The supernatant is used as the enzyme for $\beta$-amylase activity. To $0.5 \mathrm{ml}$ of $1 \%$ potato starch and $0.5 \mathrm{ml}$ of enzyme in $16 \mathrm{mM}$ sodium acetate buffer starch was added vortexed and incubated in shaker for $5 \mathrm{~min}$ at $37^{\circ} \mathrm{C}$. To this $0.5 \mathrm{ml}$ of DNS reagent was added and incubated in boiling water bath for $10 \mathrm{~min}$. Maltose was taken as standard concentration. The absorbance was read spectrophotometrically at 540nm. [19]

\section{Determination of Total Phenolics}

Fenugreek seeds $(500 \mathrm{mg})$ was soaked in $2.5 \mathrm{ml}$ of $95 \%$ ethanol and kept in the freezer for $48 \mathrm{~h}$. The sample was homogenized and centrifuged $(13000 \mathrm{rpm}, 10 \mathrm{~min})$. One $\mathrm{ml}$ of the supernatant was transferred to a test tube, and $1 \mathrm{ml}$ of $95 \%$ ethanol, $5 \mathrm{ml}$ of distilled water and $0.5 \mathrm{ml}$ of Folin-Ciocalteu phenol reagent were added. After an incubation period of $5 \mathrm{~min}, 1 \mathrm{ml}$ of 5\% Na2CO3 was added, mixed well and kept in the dark for an hour. The samples were vortexed and absorbance was measured at $725 \mathrm{~nm}$ using colorimeter. Phenolic content was reported as $\mathrm{mg} / \mathrm{g}$ fresh weight $(\mathrm{FW})$ and measured as gallic acid equivalents. [20]

\section{Osmotic stress}

Laboratory water stress was created by using Polyethylene Glycol 6000. [15] Five different water stress conditions (Control, $-0.1,-0.3,-0.6$ and $-0.9 \mathrm{MPa}$ ) were used in a completely randomized design. The osmotic

$\begin{array}{lll}\text { DOI: } 10.9790 / 264 X-03018997 & \text { www.iosrjournals.org } & 90 \mid \text { Page }\end{array}$


potential of the aqueous solutions of PEG 6000 was calculated according to the empirical equation. PEG 6000 was dissolved in water and placed in a shaker bed $\left(25^{\circ} \mathrm{C}\right)$ for $16 \mathrm{hr}$. [21]

\section{Seed germination assay}

Seed germination bioassay was carried out in sterilized Petri plates ( $9 \mathrm{~cm}$ inner diameter). The seeds were surface sterilized using $0.1 \% \mathrm{HgCl}_{2}$ for $5 \mathrm{~min}$, followed by thorough rinsing with distilled water. About 25 healthy and uniform seeds were used for germination and $15 \mathrm{ml}$ solution of respective concentration of PEG 6000 was added in each Petri plate. Seed germination bioassay was carried out at room temperature $\left(25 \pm 3^{\circ} \mathrm{C}\right)$ and uniform light conditions. Seeds were considered to be germinated with radical emergence of $1 \mathrm{~mm}$. [14]

\section{Seedling growth analysis}

Seed germination and seedling growth was investigated and recorded. Total number of germinated seeds in each Petri dish on the seventh day was regarded as the final germination percentage (FGP). Five seedlings from each treatment were selected randomly and the average plumule and radicle length were measured. Then, they were oven-dried at $50{ }^{\circ} \mathrm{C}$ for $24 \mathrm{hrs}$ to acquire their mean dry weight then the tissue water content was calculated as based on the (FW-DW/DW) ratio. [14]

\section{Determination of Protein content and total sugars}

Protein content of the seedlings was determined, were $500 \mathrm{mg}$ of seedlings were taken and homogenised with distilled water for all different concentration and centrifuged(10000g for $10 \mathrm{~min})$ the supernatant was taken and protein estimation was carried out. [22]. Total sugars content was determined by the method described by Hedge and Hofreiter, 1962. [23]

\section{Estimation of Free Proline content}

Fresh seedlings were homogenized in $3 \%$ sulphosalicylic acid. The reaction mixture containing filtrate, GAA and ninhydrin was kept in boiling water bath for $1 \mathrm{hr}$, reaction terminated in ice bath. Reaction mixture was extracted with toluene, mixed and left at room temperature for 30 min until two phase separation was achieved. Upper layer was warmed to room temperature and optical density was measured. Proline content was determined from standard curve using D-Proline. The reaction was terminated by placing the tubes in ice bath and the red colour developed by addition of toluene was measured spectrophotometrically at $520 \mathrm{~nm}$. [24]

\section{Determination of Glycine betaine content}

About 500mg of fresh seedlings were taken and were incubated in $1 \mathrm{~N} \mathrm{H}_{2} \mathrm{SO}_{4}$, homogenised and centrifuged $(12000 \mathrm{rpm}$ for $10 \mathrm{~min})$. The reaction mixture contained the supernatant, $\mathrm{H}_{2} \mathrm{SO}_{4}$ and cold $\mathrm{I}_{2} \mathrm{KI}$ reagent. The tubes were then cooled to $4{ }^{\circ} \mathrm{C}$ and centrifuged again. Ethylene dichloride was added and absorbance was recorded at $365 \mathrm{~nm}$. [25]

\section{Determination of Catalase Activity}

The assay mixture contained $0.5 \mathrm{ml}$ of $\mathrm{H}_{2} \mathrm{O}_{2}, 1.0 \mathrm{ml}$ of buffer and $0.4 \mathrm{ml}$ of water. $0.2 \mathrm{ml}$ of the enzyme was added to initiate the reaction. To this $2 \mathrm{ml}$ of the dichromate/acetic acid reagent was added after 0, 30, 6090 seconds of incubation. To the control tube the enzyme was added after the addition of the acid reagent. The tubes were then heated for 10 minutes. And then the colour developed was read at $610 \mathrm{~nm}$. [26]

\section{Heavy Metal stress}

\section{Seed material and Germination}

Seeds were collected from local plants of fenugreek and were used for the germination test. Fenugreek seeds were sterilized with $0.1 \%$ mercuric chloride for $5 \mathrm{~min}$ and washed thoroughly with distilled water. They were then placed to germinate in Petri dishes, distilled water (control) and heavy metal of lead nitrate $(0.01,0.02$ $0.03 \mathrm{mg})$ at room temperature $\left(25^{\circ} \mathrm{C}\right)$ in light. In each treatment, 5 Petri dish (each one contained 25 seeds) was used. The seeds were considered germinated when the radicle reached $2 \mathrm{~mm}$, cumulative germination percentage was determined. [14]

\section{Seedling analysis}

Germinated seeds in distilled water and in heavy metal solutions were sampled after 7 days from the beginning of incubation and then germination process was stopped. A part of these tissues were weighed to obtain the fresh weight. The dry weight was obtained after drying the tissue at $50^{\circ} \mathrm{C}$ for $24 \mathrm{~h}$; then the tissue water content was calculated as based on the (FWDW/DW) ratio. [14]

\section{Determination of protein constituents}

Protein content of the seedlings was determined, were $500 \mathrm{mg}$ of seedlings were taken and homogenised with distilled water for all different concentration and centrifuged(10000g for $10 \mathrm{~min})$ the supernatant was taken and protein analysis was carried out. [22] 


\section{Estimation of Free proline content}

Fresh seedlings were homogenized in $3 \%$ sulphosalicylic acid. The reaction mixture containing filtrate, GAA and ninhydrin was kept in boiling water bath for $1 \mathrm{hr}$, reaction terminated in ice bath. Reaction mixture is extracted with toluene mixed and left at room temperature for $30 \mathrm{~min}$ until two phase separation happens. Upper layer is warmed to room temperature and optical density measured. Proline content is determined from standard curve using D-Proline. The reaction was terminated by placing the tubes in ice bath and the red colour developed by addition of toulene was measured at $520 \mathrm{~nm}$. [24]

\section{Determination of Soluble sugars}

Three replicates of cotyledons or axes samples of germinated seeds were suspended in test tubes with 3 $\mathrm{ml}$ of $80 \%$ ethanol, the extract was evaporated to dryness in hot air oven and the residue was dissolved in $20 \mathrm{ml}$ of distilled water. Total soluble sugars were determined by the phenol sulphuric acid method using glucose as standard. [18]

\section{Salt stress}

\section{Results And Discussion}

The influence of $\mathrm{NaCl}$ on the growth and water content of embryonic axes and cotyledons in germinated seeds was studied. In the cotyledons the FW (fresh weight) values showed significant differences between control and salt solution. However, in embryonic axes, the FW values decreased by $50 \mathrm{mM} \mathrm{NaCl}$ treatment. The DW (dry weight) displayed significant differences on one hand between control and $100 \mathrm{mM}$ $\mathrm{NaCl}$ treatment. In embryonic axes, between control and $50 \mathrm{mM} \mathrm{NaCl}$ treatment on the other hand. Further, a significant decrease in water content of embryonic axes was observed from $40 \mathrm{mM} \mathrm{NaCl}$. The lowest value of this parameter was observed at 50 and $100 \mathrm{mM} \mathrm{NaCl}$. In cotyledons, the water content varied only slightly at this stage of germination (radicles length $2 \mathrm{~mm}$ ) water content vary from $3.289(0 \mathrm{mM} \mathrm{NaCl})$ to $0.887(100 \mathrm{mM}$ $\mathrm{NaCl})$.

\begin{tabular}{|l|l|l|l|l|l|}
\hline Embryonic Axes & Control & \multicolumn{4}{l|}{ Concentration of NaCl $(\mathbf{m M})$} \\
\hline & & $\mathbf{1 0 m M}$ & $\mathbf{3 0 m M}$ & $\mathbf{5 0 m M}$ & $\mathbf{1 0 0} \mathbf{m M}$ \\
\hline FW $(\mathrm{mg})$ & $24.2 \pm 3.340$ & $22.467 \pm 1.234$ & $22 \pm 1.562$ & $18.533 \pm 2.541$ & $13.933 \pm 0.521$ \\
\hline DW(mg) & $3.000 \pm 0.230$ & $3.5333 \pm 0.581$ & $3.666 \pm 0.405$ & $3.8666 \pm 0.176$ & $4.000 \pm 0.346$ \\
\hline Relative water Content & $7.332 \pm 1.802$ & $5.637 \pm 0.9323$ & $5.203 \pm 1.0392$ & $3.793 \pm 0.6425$ & $2.560 \pm 0.4418$ \\
\hline Cotyledons & $\mathbf{1 0 m M}$ & $\mathbf{3 0} \mathbf{m M}$ & $\mathbf{5 0 m M}$ & $\mathbf{1 0 0 m M}$ & \\
\hline FW(mg) & $32.933 \pm 2.257$ & $27.333 \pm 7.802$ & $25.8 \pm 1.803$ & $24.933 \pm 3.1205$ & $23.266 \pm 3.5802$ \\
\hline DW(mg) & $8.8 \pm 1.800$ & $9.333 \pm 1.034$ & $9.8 \pm 0.416$ & $10.6 \pm 1.858$ & $12.266 \pm 0.466$ \\
\hline Relative water content & $3.289 \pm 1.344$ & $1.828 \pm 0.484$ & $1.646 \pm 0.236$ & $1.459 \pm 0.459$ & $0.887 \pm 0.258$ \\
\hline
\end{tabular}

Table 1: Effect of salinity stress on relative water content of fenugreek seeds

(Values are expressed as mean $\pm S D, n=3$ )

Fenugreek seeds do not contain starch as carbohydrate reserve. Synthesis of starch is initiated after germination. As starch is determined in certain amount after germination. Figure 2 shows the influence of $\mathrm{NaCl}$ concentrations on starch level in cotyledons. During germination, the amount of starch in embryos increased clearly in control (seeds treated with distilled water) and cotyledons treated with $\mathrm{NaCl}$ contained lower levels of starch than that treated with distilled water. Gradual Decrease of starch amount was observed in cotyledons of seeds treated with different concentration of $\mathrm{NaCl}$. A large decrease of starch was observed in cotyledon treated with control and $100 \mathrm{mM} \mathrm{NaCl}$.

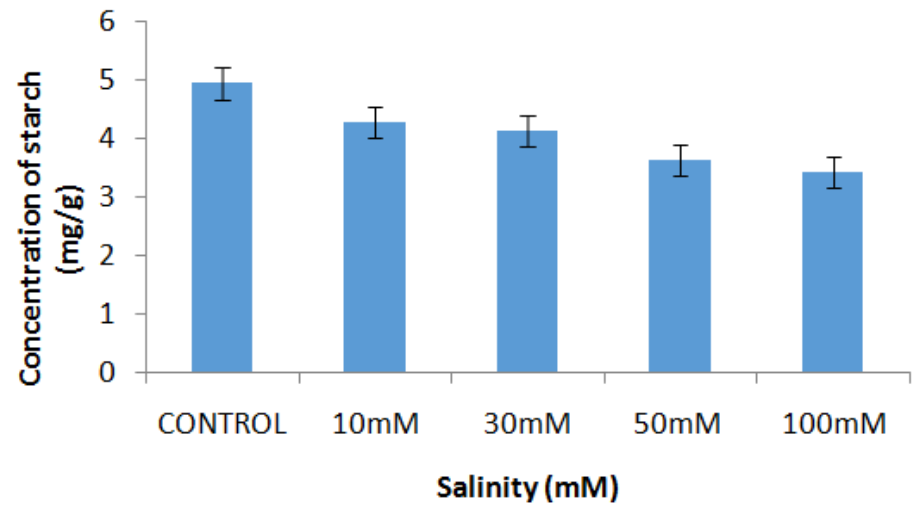

Figure 1: Changes in levels of starch in cotyledons of germinating fenugreek seeds treated with distilled water (control) and saline solutions 
The activity of $\beta$ - amylase detected in seeds germinated in the control treatment was higher compared to those detected in stressed seeds. Fig. 3 shows the influence of the presence of various concentrations of $\mathrm{NaCl}$ on the $\beta$-amylase activity in cotyledons of germinated seeds. The activity of this enzyme showed decreasing trend at $50 \mathrm{mM}$ and showed slight increase in $10 \mathrm{mM}$ and $30 \mathrm{mM}$ when compared to control but was negligible (about $0.02 \mathrm{mg} / \mathrm{ml}$ ). B-Amylase activity decreased particularly by $61.3 \%$ in $100 \mathrm{mM}$ concentration.

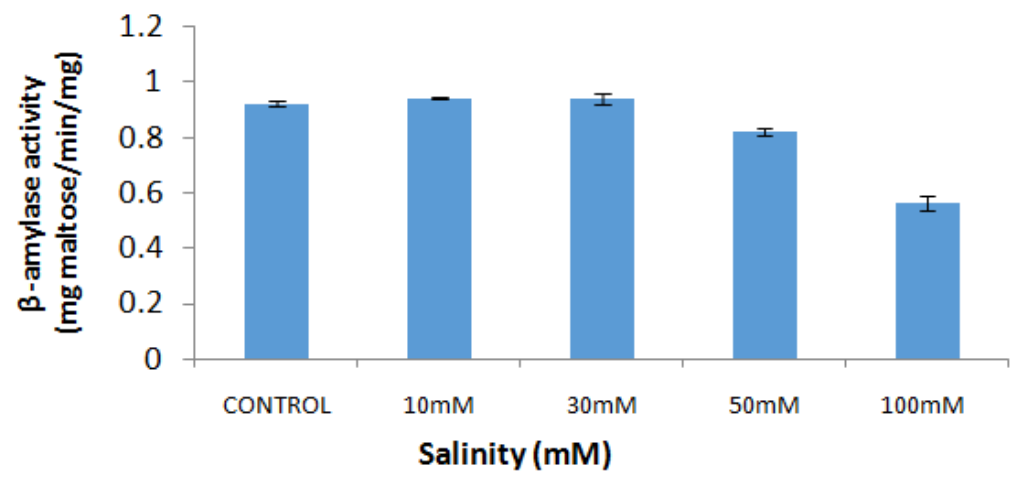

Figure 2: Influence of $\mathrm{NaCl}$ on the activity of amylase in cotyledons of germinating fenugreek seeds

The total phenolics content of germinated fenugreek seeds was different across $\mathrm{NaCl}$ treatments (Fig.3); within untreated fenugreek seeds contain $0.58 \mathrm{mg} / \mathrm{g}$. The amount of GAE $\mathrm{mg} / \mathrm{g}$ increased with salinity, principally, seeds treated with 30 and $100 \mathrm{mM} \mathrm{NaCl}$ showed the greater accumulation of polyphenols which was around $0.76 \mathrm{mg} / \mathrm{g}$ and $0.778 \mathrm{mg} / \mathrm{g}$.

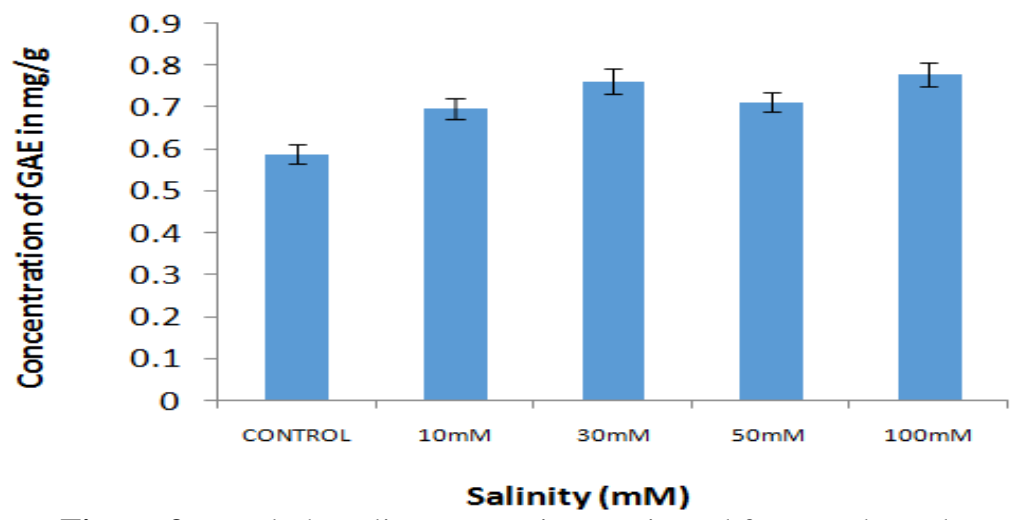

Figure 3: Total phenolics content in germinated fenugreek seeds

The influence of salinity levels on total soluble sugar content of germinated seeds is shown in fig. 4 compared with control, imposition of $\mathrm{NaCl}$ treatment resulted in a significant increase in total sugar content in cotyledons, The level of total soluble sugars increased to a smaller extent over stressed seeds in cotyledons, no significant differences were displayed under different salt conditions. Under the influence of high concentrations of $\mathrm{NaCl}$ (50 to $100 \mathrm{mM}$ ) soluble sugars in cotyledons was around $63.85 \mathrm{mg} / \mathrm{g}$ and $67.22 \mathrm{mg} / \mathrm{g}$.

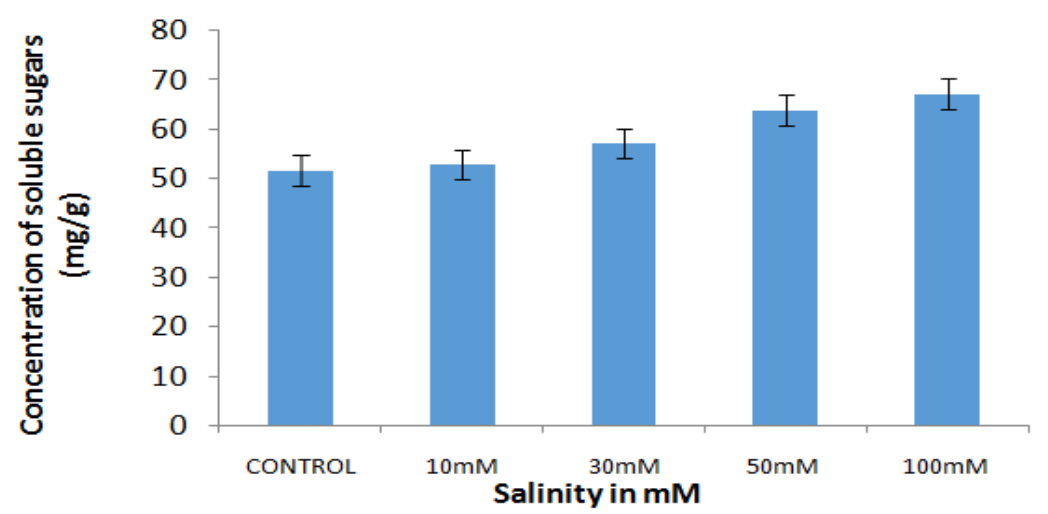

Figure 4: Total soluble sugar content (mg/g FW) in cotyledons of fenugreek seeds 


\section{Osmotic stress}

Relative water content was highest in control, $-0.1 \mathrm{MPa}$ and there was a significant decline in final relative water content with decrease in osmotic potential as shown in table 2. The fresh weight decreased significantly with increase in PEG concentration and a negligible increase in dry weights was observed. High concentration of PEG might hamper the process of water uptake by seeds and thereby inhibiting the process of seed germination.

\begin{tabular}{|l|l|l|l|l|l|}
\hline & Control & $-0.1 \mathrm{MPa}$ & $-0.3 \mathrm{MPa}$ & $-0.6 \mathrm{MPa}$ & $-0.9 \mathrm{MPa}$ \\
\hline Fresh weight $(\mathrm{mg})$ & $0.316 \pm 0.0738$ & $0.331 \pm 0.0241$ & $0.315 \pm 0.0432$ & $0.259 \pm 0.0111$ & $0.258 \pm 0.0340$ \\
\hline Dry weight $(\mathrm{mg})$ & $0.061 \pm 0.007$ & $0.0623 \pm 0.011695$ & $0.0683 \pm 0.0100$ & $0.0683 \pm 0.0048$ & $0.070 \pm 0.0104$ \\
\hline Relative water content & $4.050 \pm 0.310$ & $4.542 \pm 0.419$ & $3.717 \pm 0.591$ & $2.804 \pm 0.056$ & $2.685 \pm 0.064$ \\
\hline
\end{tabular}

Table 2: Effect of different levels of osmotic stress on relative water content of fenugreek seeds

PEG induced osmotic stress caused a significant reduction in protein content (Fig.5) of treated seedlings as compared to control. There was about $45.75 \%$ reduction in protein content at osmotic potential of $0.9 \mathrm{MPa}$ as compared to control.

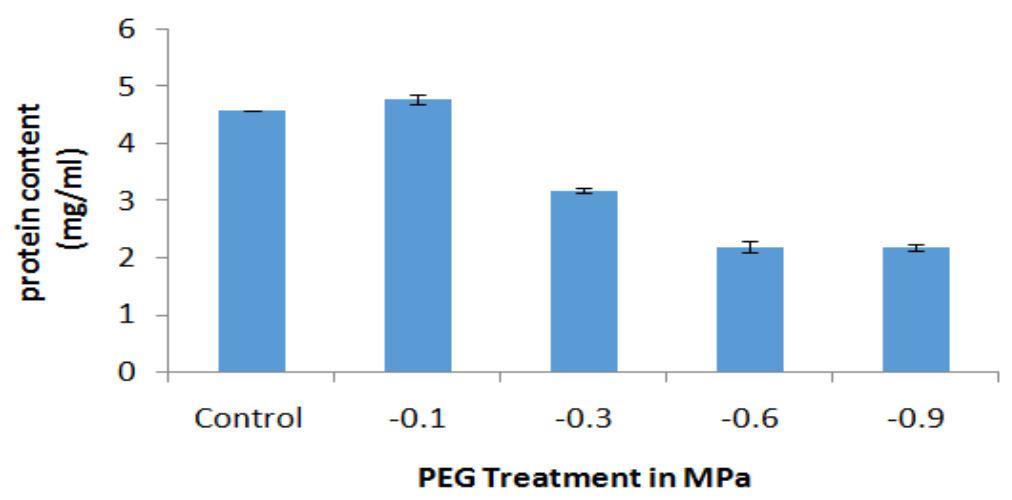

Figure 5: Effect of different levels of osmotic stress on total protein content of fenugreek seeds

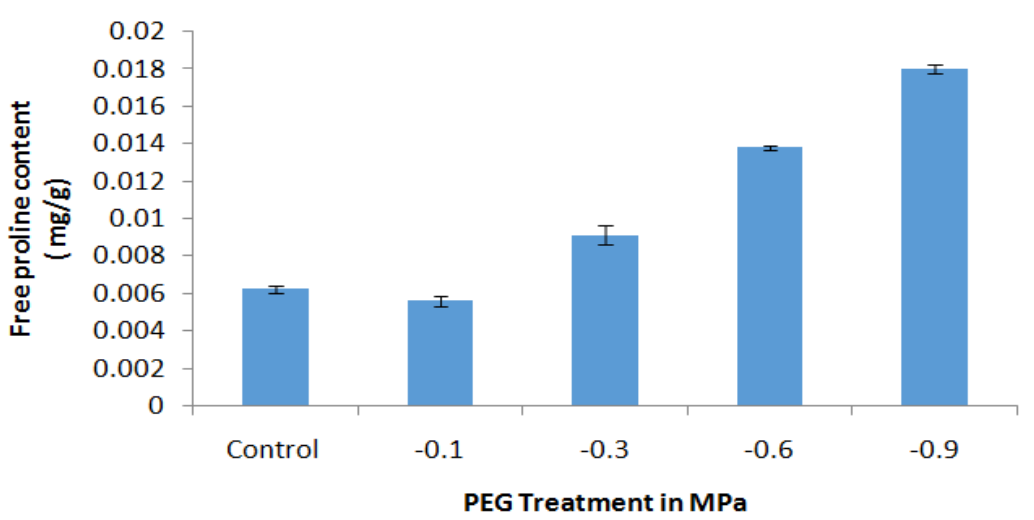

Figure 6: Effect of different levels of osmotic stress on free proline content of fenugreek seeds

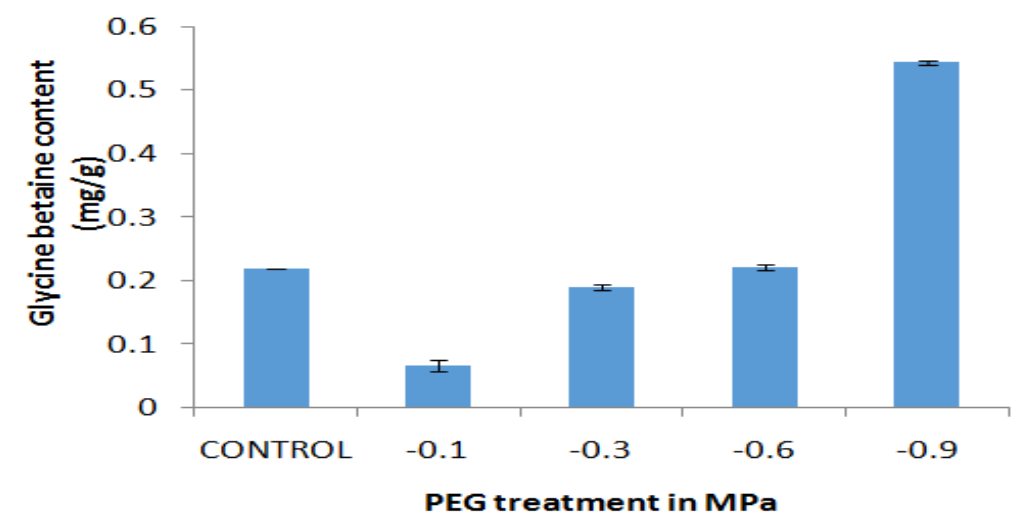

Figure 7: Effect of different levels of osmotic stress on glycine betaine content of fenugreek seeds. 
Experimental findings on antioxidant system indicate that responded differently under normal and water stress conditions. Decrease in osmotic potential showed significant increase in antioxidant contents like proline and glycine betaine as compared to control. (Fig. 6 and 7). Proline and glycine betaine content was significantly increased with decreasing osmotic potential. During stress conditions, protein degrades and consequently the proline and glycine betaine increases. High level of proline enabled the plant to maintain low water potentials.

CAT activity increased sharply in relative to the control. This enzyme activity increased gradually upto the level of -0.9 PEG, and higher than the control. Furthermore, water stress induced a significant increase in CAT activity in all the treatments. Comparatively it showed higher CAT activity in control than that of -0.1 PEG concentrations. (Fig. 8)

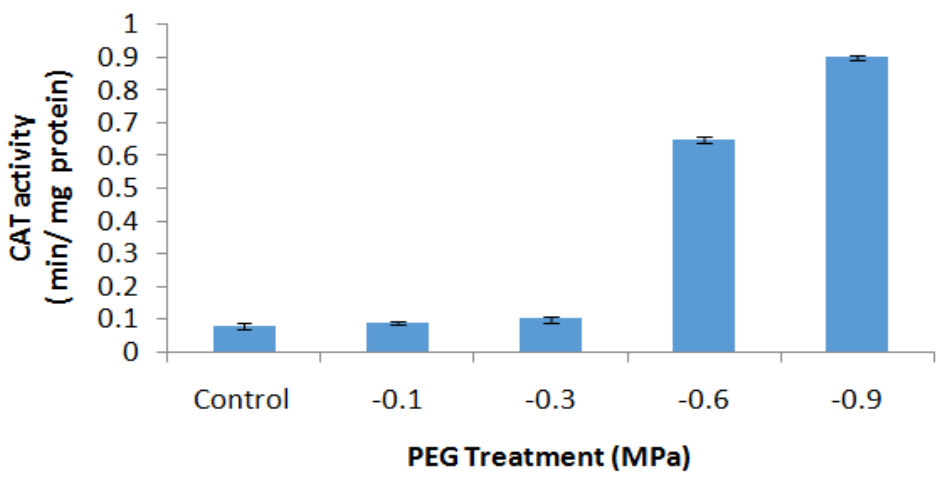

Figure 8: Effect of different levels of osmotic stress on catalase activity content of fenugreek seeds.

\section{Heavy metal stress}

The heavy metals treatment with $\mathrm{Pb}$ markedly decreased relative water content. seed germination was consistently reduced with increased concentration of lead $(\mathrm{Pb})$ and maximum suppression of plant growth was recorded at the highest concentration of heavy metals $\mathrm{Pb}$ ) at whose relative water content was reduced up to $49.4 \%$ as compared to control. (Table 3 )

\begin{tabular}{|l|l|l|l|l|}
\hline Radicle & Control & \multicolumn{3}{|l|}{ Concentration of $\mathbf{P b} \mathbf{( m g} / \mathbf{m L})$} \\
\cline { 3 - 5 } & & $\mathbf{1 0 m g} / \mathbf{m L}$ & $\mathbf{2 0} \mathbf{m g} / \mathbf{m L}$ & $\mathbf{3 0 m g} / \mathbf{m L}$ \\
\hline Fresh weight $(\mathrm{mg})$ & $10.020 \pm 0.0075$ & $8.500 \pm 0.0110$ & $8.530 \pm 0.0075$ & $6.320 \pm 0.003$ \\
\hline Dry weight $(\mathrm{mg})$ & $7.50 \pm 0.0025$ & $8.5000 \pm 0.0005$ & $1.20 \pm 0.003$ & $1.110 \pm 0.002$ \\
\hline Relative water content & $9.326 \pm 0.0077$ & $7.352 \pm 0.0183$ & $5.733 \pm 0.0183$ & $4.454 \pm 0.0197$ \\
\hline Cotyledons & & & & \\
\hline Fresh weight $(\mathrm{mg})$ & $26.900 \pm 0.0055$ & $25.400 \pm 0.013$ & $22.000 \pm 0.013$ & $21.5 \pm 0.014$ \\
\hline Dry weight $(\mathrm{mg})$ & $5.450 \pm 0.0015$ & $4.7000 \pm 0.0085$ & $4.5000 \pm 0.0019$ & $3.5 \pm 0.0021$ \\
\hline Relative water content & $4.404 \pm 0.0106$ & $3.962 \pm 0.0155$ & $3.944 \pm 0.010$ & $3.888 \pm 0.0043$ \\
\hline
\end{tabular}

Table 3: Effect of different levels of heavy metal stress on relative water content of fenugreek seeds (Values are expressed as mean $\pm S D, n=3$ )

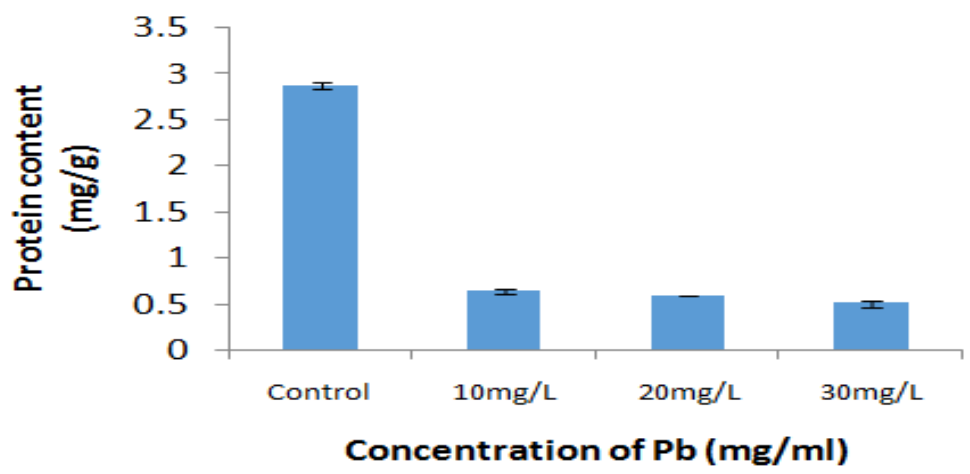

Figure 9: Effect of heavy metal on protein content of fenugreek seeds

The protein content under heavy metal stress found more pronounced decrease in the protein content with $\mathrm{Pb}$ treatment. The decrease in protein content may be caused by enhanced protein degradation process as a result of increased protease activity that is found to increase under stress conditions. It was about $82 \%$ decrease in the protein content in 30mg/l when compared with control as shown in fig. 9. 


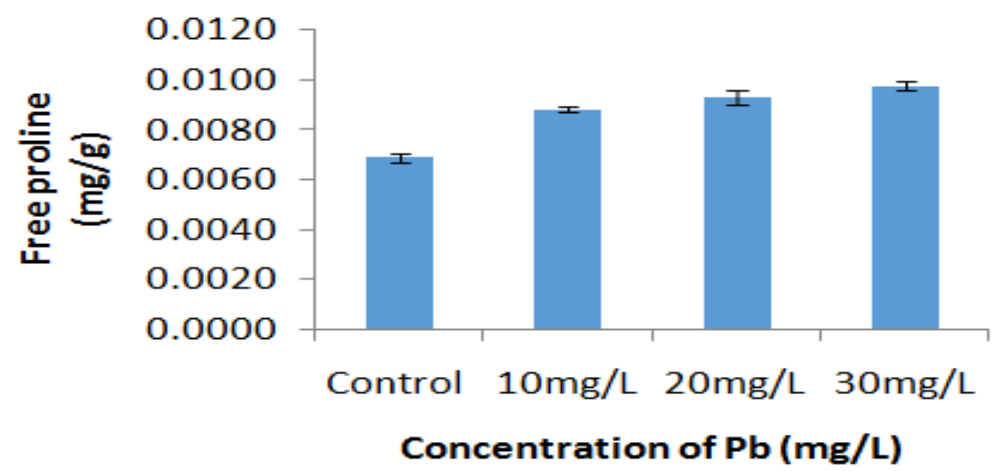

Figure 10: Effect of different levels of metal stress on free proline content of Fenugreek seeds.

Significant increase in contents of proline was noted in seedlings of fenugreek seeds treated with different concentrations of $\mathrm{Pb}$ as compared to control with maximum accumulation in $30 \mathrm{mg} / \mathrm{Pb}$ treated seedlings as shown in fig. 10.

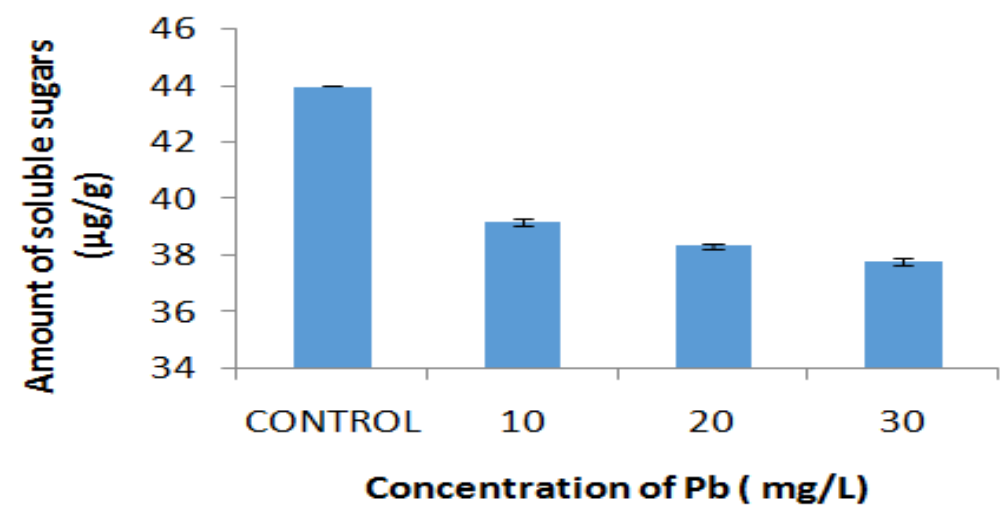

Figure 11: Effect of different levels of Metal Stress on total soluble sugar content of Fenugreek Seeds

The results related to the soluble sugar content are depicted in above Fig. 11, which revealed that lower concentration $\mathrm{Pb}$ (lead) increased the soluble sugar content; however, higher concentrations of $30 \mathrm{mg} / \mathrm{lof} \mathrm{Pb}$ showed a decrease of $85.9 \%$ in soluble sugar content compared to control.

\section{Conclusion}

The results from the present study indicate that with the increasing concentration of abiotic stress induced on the Trigonella foenum-graecum seeds, it resulted in reduced seed germination and it also caused subsequent metabolic changes. In the case of salt stress, we observed that as the salt concentration increased there was proportional increase in total phenolics and soluble sugars whereas there was a decrease in starch content and beta amylase activity. It had a negative impact on seed germination. It can also be observed that, water is a major limiting factor for seed germination and osmotic potential plays an important role, as it decreases protein content decreases but antioxidant contents increased. As the concentration of PEG 6000 increased the germination percentage of the seed decreased. Heavy metal stress in plants and seeds decreases the relative water content, soluble sugar content and protein contents due to increase in the protease activity consistently the seed germination reduced with increased in heavy metal stress which hinders the metabolic processes, growth of the plants and the crop yield.

\section{References}

[1]. Saroj KS, Kambham RR and Li JX, Abscissic acid and abiotic stress tolerance in crop plants, Frontiers in Plant Sci., 5(7), 2016, 571

[2]. R. Munns and M. Tester, Mechanisms of salinity tolerance, Annual Review of Plant Biology, vol. 59, 2008, 651-681

[3]. R. A. James, C. Blake, C. S. Byrt, and R. Munns, Major genes for Na+ exclusion, Nax1 and Nax2 (wheat HKT1;4 and HKT1;5), decrease $\mathrm{Na}+$ accumulation in bread wheat leaves under saline and waterlogged conditions, Journal of Experimental Botany, 62 (8), 2011, 2939-2947

[4]. A. Rahnama, R. A. James, K. Poustini, and R. Munns, Stomatal conductance as a screen for osmotic stress tolerance in durum wheat growing in saline soil,Functional Plant Biology, 37( 3), 2010, 255-263

[5]. R. Munns, Genes and salt tolerance: bringing them together, New Phytologist, 167 (3), 2005, 645-663

[6]. Rozema, J. and Flowers, T., Ecology: Crops for a Salinized World, Science, 322, 2008, 1478-1480

[7]. K. Apel and H. Hirt, Reactive oxygen species: metabolism, oxidative stress, and signal transduction Annual, Review of Plant Biology, 55, 2004, 373-399 
[8]. S. Mahajan and N. Tuteja, Cold, salinity and drought stresses: an overview, Archives of Biochemistry and Biophysics, 444(2), 2005, 139-158

[9]. P. Ahmad, Growth and antioxidant responses in mustard (Brassica juncea L.) plants subjected to combined effect of gibberellic acid and salinity, Archives of Agronomy and Soil Science, 56(5), 2010, 575-588

[10]. Srinivasan Malar, Sahi Shivendra Vikram, Paulo J.C Favas and Venkatachalam Perumal, Lead heavy metal toxicity induces changes on growth and antioxidative enzymes level in water hyacinths (Echhornia crassipes (Mart.). Botanical Studies, 55(1), 54, 2014, 1-11.

[11]. Sharma P. and Duby R.S., Lead toxicity in plants, Brazil J. Plant Physiol., (17), 2005, 35-52

[12]. Heath R.L. and Packer K., Leaf Senescence correlated with increased levels of membrane permeability and lipid peroxidation and decreased levels of superoxide dismutase and Catalase. J. Exp. Bot., (32), 1968, 93-101

[13]. Lin C.J., Liu L., Liu T., Zhu L., Sheng D. and Wang D., Soil amendment application frequency contributes to phytoextraction of lead by sunflower at different nutrient levels. Environment Experimental Botany, 65, 2009, 410-416

[14]. Fernando E. Prado, Cecilia Boero, Miriam Gallardo, Juan A. González Effect of NaCl on germination, growth, and soluble sugar, Bot. Bull. Acad. Sin., 2000, 41: 27-34

[15]. Yogita Rohamare, K.N. Dhumal and T.D. Nikam, Yogita Rohamare, K.N. Dhumal and T.D. Nikam, Response of Ajowan to water stress induced by polyethylene glycol during seed germination and seedling growth, Journal of Environmental Biology , 35(5), 2014, 789-93

[16]. Gurpreet Kaur ,Harminder Pal Singh, Daizy R. Batish, Ravinder Kumar Kohl, Growth, photosynthetic activity and oxidative stress in wheat (Triticum aestivum) after exposure of lead to soil, J. Environ. Biol., 33, 2012, 265-269

[17]. Allefrey JM, Northcote DH, The effects of the axis and plant hormones on the mobilization of storage materials in the groundnut (Arachis hypogaea) during germination. New Phytol, 1977, 78

[18]. Dubois, M., K.A. Gilles, J.K. Hamilton, P.A. Rebers and F. Smith, Colorimetric method for determination of sugars and related substances. Anal. Chem. 28, 1956, 350-356

[19]. Bernfeld P, Amylase $\alpha$ and $\beta$, In Methods in Enzymology, (Colowick SP, Kaplan NO, ed.), Academic Press Inc, New York (1), $1955,149-158$

[20]. Kwok D, Shetty K., Pseudomonas spp.-mediated regulation of total phenolics and rosmarinic acid in shoot-based clonal lines of thyme (Thymus vulgaris L.), J. Food. Biochem, 20, 1996, 365-377

[21]. Michel, B.E. and M.R. Kaufmann, The osmotic potential of polyethylene glycol 6000, Plant Physiol., 51, 1973, 914-916

[22]. Lowry O H, NJ Rosebrough, AL Farr, RJ Randall, Protein measurement with the Folin-Phenol reagents, J. Biol. Chem., 193, 1951, 265-275

[23]. Hedge, J.E. and Hofreiter, B.T, In: Methods in Carbohydrate Chemistry. Vol.17, (Eds.,) Whistler, R.L. and BeMiller, J.N., Academic Press, New York, 1962, 420

[24]. Bates L, Waldren RP, Teare ID., Rapid determination of free proline for water-stress studies, Plant and Soil, 39, 1973, 205-207

[25]. Ishitani, M., Arakawa, K., Mizuno, K., Kishitani, S. and Takabe, T., Betaine aldehyde dehydrogenase in the Gramineae: levels in leaves of both betaine-accumulating and nonaccumulating cereal plants, Plant Cell Physiol. 34, 1993, 493-495

[26]. Sinha A.K., Colorimetric assay of catalase, Anal. Biochem. 47, 1972, 389 - 394 